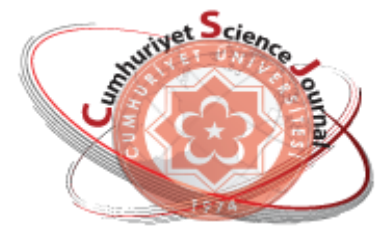

e-ISSN: $2587-246 X$

ISSN: $2587-2680$

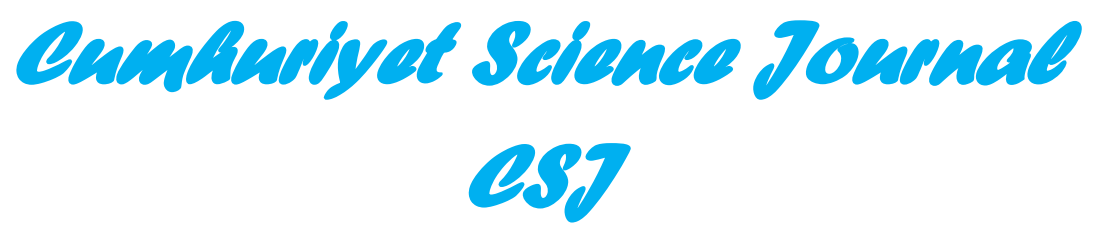

Cumhuriyet Sci. J., Vol.39-2(2018) 380-388

\title{
Electron Paramagnetic Resonance Investigation of Radiation Effect on Certain Types of Drug Powders
}

\author{
Şemsettin OSMANOGLU ${ }^{I^{*}}$, Kerem SUTCU ${ }^{2}$ \\ ${ }^{1}$ Dicle University, Faculty of Science, Department of Physics, Diyarbakır, TURKEY \\ ${ }^{2}$ Dicle University, Faculty of Education, Department of Science Education, Diyarbakur, TURKEY \\ Received: 05.02.2018; Accepted: 03.05.2018 \\ http://dx.doi.org/10.17776/csj.390570
}

\begin{abstract}
In this study, gamma rays were applied to the sulfadimethoxine, pyrazinamide, and chloramphenicol in the dose range of 1-15 kilogray, in order to detect radiosensitivity of paramagnetic species, which are formed after irradiation by electron paramagnetic resonance spectroscopy. Firstly, the intensities of electron paramagnetic resonance signals of the samples as a function of the microwave power were investigated at room temperature. While no signal was obtained from the unirradiated samples, the irradiated samples exhibited significant spectra. Additionally, the time dependency of the samples was analyzed to study the stability of the radicals.
\end{abstract}

Keywords: Electron Paramagnetic Resonance, Free radicals, Drug.

\section{Bazı İlaç Tozlarında Radyasyon Etkisinin Elektron Paramanyetik Rezonans İncelenmesi}

\begin{abstract}
Özet: $\mathrm{Bu}$ çalışmada, elektron paramanyetik rezonans spektroskopisi ile ışıılama sonrası oluşan paramanyetik türlerin radyasyon duyarlılığını saptamak için sülfadimetoksin, pirazinamid ve kloramfenikol numunelerine 115 kilogray dozunda gama ışınları uygulandı. İlk olarak, numunelerin elektron paramanyetik rezonans sinyal şiddetleri, mikrodalga gücünün bir fonksiyonu olarak oda sıcaklığında incelendi. Işınlanmamış örneklerden herhangi bir sinyal elde edilmezken, ışınlanmış numuneler belirgin spektrumlar sergiledi. Ek olarak, radikallerin kararlılıklarını incelemek amacıyla numunelerin zamana bağımlılı̆̆ı analiz edildi.
\end{abstract}

Anahtar Kelimeler: Elektron Paramanyetik Rezonans, Serbest radikaller, İlaç.

\section{INTRODUCTION}

Sterilization is a process of inactivating microorganisms that can be anywhere, anytime [1]. While determining the methods to be used in sterilization, properties such as type and structure of the material should be taken into account; because there is no ideal method of sterilization for each material. Currently, the sterilization method using radiation is often benefited in order to improve hygienic quality of the food, drugs and pharmaceutical raw materials, disposable medical products as well as to prolong their shelf lives and prevent food borne diseases [2-4]. Because, thanks to the powerful penetration ability of gamma rays, sterilization method with radiation can be applied to the product to be sterilized even in the final packaging stage of the product and it doesn't leave any chemical residues behind [5]. In addition, the product sterilized with gamma rays doesn't display any radioactivity and its

\footnotetext{
* Corresponding author. Email address: sems@dicle.edu.tr

http://dergipark.gov.tr/csj @2016 Faculty of Science, Cumhuriyet University
} 
temperature doesn't increase [6]. However, in addition to these advantages, gamma rays have also some disadvantages due to their high energies. Free radicals created in the product by gamma rays and the regulations vary from country to country in respect to method of irradiation are some of these disadvantages [7]. Therefore, the consumers would like to know whether the product, which they will consume, was exposed to any radiation application; and the amount of dose in $\mathrm{kGy}$, if it was exposed to radiation [8]. As a result, it is necessary to investigate the radiation sensitivity of the raw materials of drugs to be exposed to radiosterilization. Electron Paramagnetic Resonance (EPR) spectroscopy is one of the leading methods used to investigate the radiation sensitivity of irradiated samples of food and drugs $[9,10]$.

Gamma radiation effects on metronidazole, which is an antibacterial agent, were investigated by Basly et al.[11]. The free radicals evolution with dose was quasi-linear from 1 to $50 \mathrm{kGy}$. The variations of the heights of sulfatiazole, one of the commonly used sulfonamides as an antibacterial agent in drugs, with applied microwave power were studied [12]. The heights of the peak saturated with different rates as inhomogenously broadened resonance lines do. This behaviour of resonance peak indicated different radical species in the studied sample. $\gamma$-radiolysis of some antibiotics were studied by Miyazaki et. al.[13]. The radicals were observed by EPR even after storage time of the irradiated samples for ca. 150 days. (ca.: abbreviation of "circa", meaning approximately)

Sulfadimethoxine (SD), Pyrazinamide (PA) and Chloramphenicol (CP) are biologically very important antibiotics. SD is a sulfonamide that is widely used to treat many types of coccidiosis [14]. Sulfonamides are chemotherapeutic drugs used for the treatment of bacterial infections in human. PA, which is poorly water soluble, white and in the form of crystalline powder, is used in the treatment of tuberculosis [15]. CP is a broad spectrum antibiotic used for the treatment of typhoid, dysentery and ocular bacterial infections [16]. Due to the fact that irradiation at low doses has the advantage of minimizing the damage to the products, [17] up to $15 \mathrm{kGy}$ of irradiated SD, PA, and CP samples were used in this study. It has been aimed to determine radiation sensitivities of free radicals formed in the structure of SD, PA and CP drug samples using EPR technique after getting irradiated by certain doses of gamma rays.

\section{MATERIALS and METHODS}

For the study purpose, SD, PA and CP samples were supplied from commercial sources in powder form. The chemical formulas and molecular weight of SD, PA and CP were given in Table 1. The samples were irradiated with ${ }^{60} \mathrm{Co} \gamma$-ray source (Isotope, Ob-Servo Sanguis) to $15 \mathrm{kGy}$ at room temperature and EPR measurements were taken over a period of several months in order to follow the stability of the radicals formed after irradiation. The EPR measurements were conducted in a Varian E109 Line Century Series EPR spectrometer operating at microwave power $1 \mathrm{~mW}$, microwave frequency of $9.2 \mathrm{GHz}$. The $\mathrm{g}$ factors were calibrated by comparison with a DPPH sample ( $\mathrm{g}=2.0036$ ). Additionally, SEM analysis was done using a FEI FEG 250 electron microscope.

Table 1. Chemical list of SD, PA, and CP samples.

\begin{tabular}{ll}
\hline $\begin{array}{c}\text { Symbol Formula } \\
\text { Molecular Weight } \\
\text { (g/mol) }\end{array}$ & $\begin{array}{c}\text { Chemical } \\
\text { structure }\end{array}$ \\
\hline $\mathrm{SD} \quad$ & \\
$\mathrm{C}_{12} \mathrm{H}_{14} \mathrm{~N}_{4} \mathrm{O}_{4} \mathrm{~S}$ & \\
310.33 & $\mathrm{PA}$ \\
$\mathrm{C}_{5} \mathrm{H}_{5} \mathrm{~N}_{3} \mathrm{O}$ &
\end{tabular}




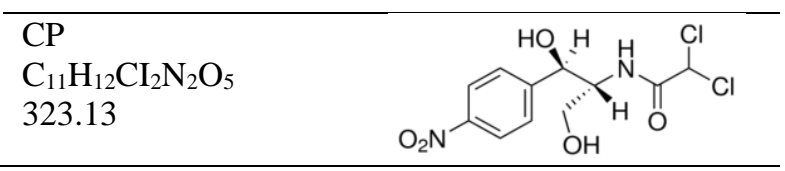

\section{RESULTS and DISCUSSION}

\subsection{Microwave Studies}

It is important to analyse the changes occurring in EPR signal intensities depending on the microwave power in terms of conducting experiments within the range of power values under microwave power saturation values [18]. In this regard, firstly the changes in signal intensities depending on microwave power of three drug samples, which are irradiated by gamma rays within a dose of $15 \mathrm{kGy}$, were investigated. Microwave power saturation changes of irradiated SD, PA and CP are given in Figs. 13 , respectively. In the calculations made by examining the spectra obtained from the SD and PA samples, it was determined that the EPR signal intensity of the SD represents the best compatibility with polynomial function, however, PA represents the best compatibility with the logarithmic function. Besides, the curve obtained from the signal labelled with $\mathrm{I}_{1}$ showed a logarithmic development, whereas curves labelled with $I_{2}$ and $I_{3}$ showed linear development. This shows that the origin of free radicals induced in gamma-irradiated CP is different [19].

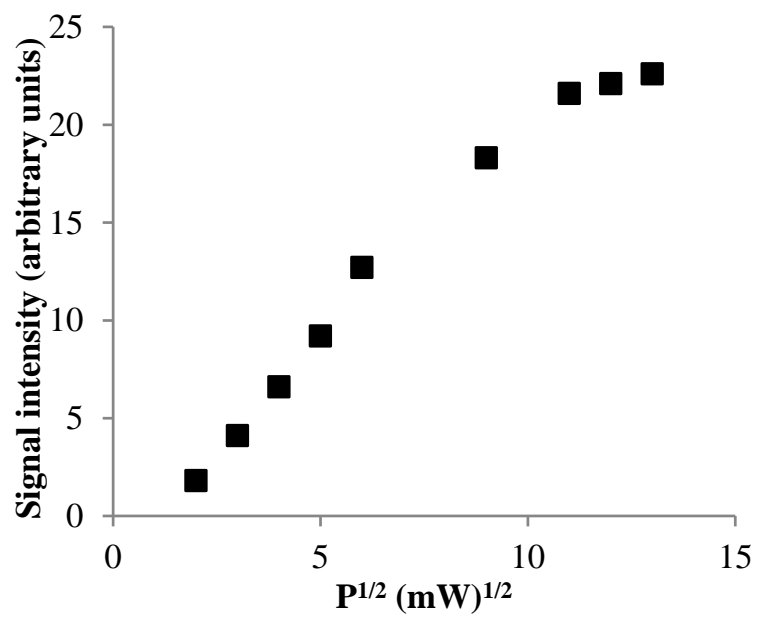

Figure 1. Variations of the EPR peak intensities of 15 $\mathrm{kGy}$ irradiated SD sample with square root of applied microwave power $(\mathrm{P})$.

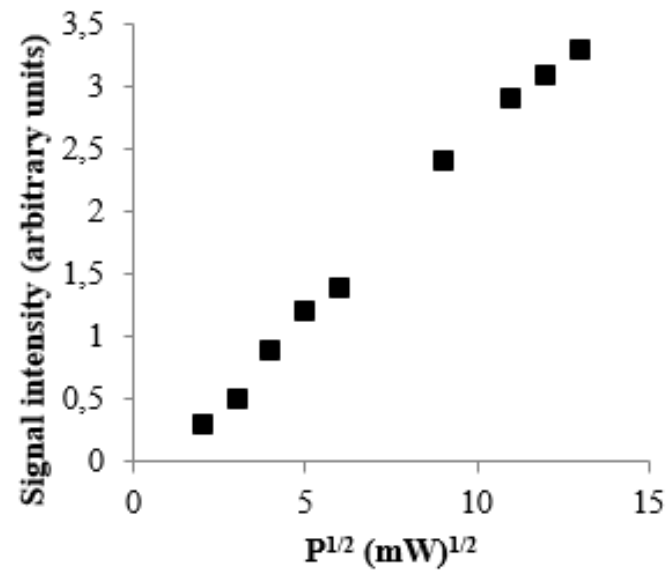

Figure 2. Variations of the EPR peak intensities of 15 kGy irradiated PA sample with square root of applied microwave power $(\mathrm{P})$.

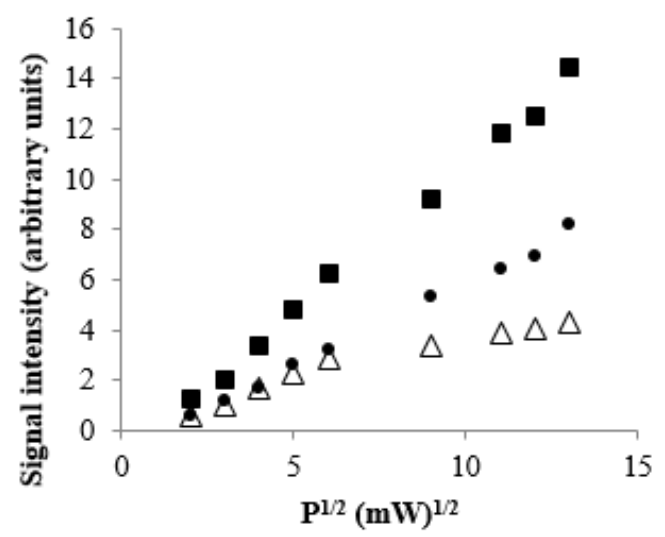

Figure 3. Variations of the EPR peak intensities of 15 kGy irradiated CP sample with square root of applied microwave power $(P)$. Signal $I_{1}(\Delta)$, Signal $I_{2}(\boldsymbol{\square})$, Signal $\mathrm{I}_{3}(\bullet)$.

\subsection{Dose-Response Curves}

Aside from qualitative detection EPR can be used for dose estimation [18,20]. Therefore, the effect of increasing radiation dose on the spectra of drugs was studied. Despite the increasing dose of radiation, no change was observed in the form of spectra, but signal intensities appeared to increase significantly. The increases in the peak-to-peak distance of the EPR spectra signals reveal that the number 
of the free radicals increases in the samples after the irradiation [21,22]. When each spectrum was examined separately, a significant change in $\mathrm{g}$ and $\Delta \mathrm{H}$ values was not determined despite the increased dose of radiation. The EPR spectra of SD, PA, and CP recorded at room temperature are shown in Figs. 4-6, respectively. The measured values of g-factors of SD, PA and CP are 2.0022 $\pm 0.0005,2.0003$ \pm 0.0005 and $2.0093 \pm 0.0005$, respectively. The $\mathrm{g}$ values of these samples seem to be in agreement with literature [23-25].

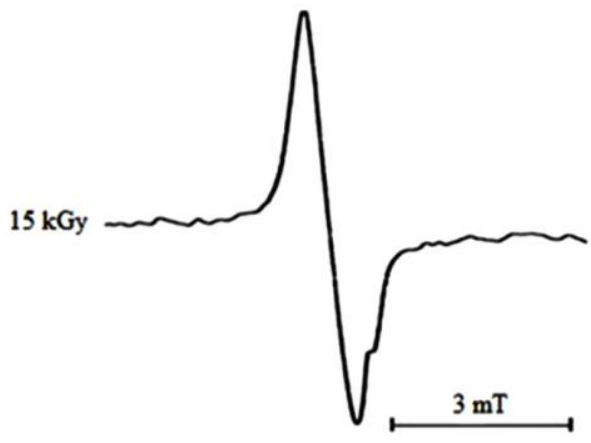

Figure 4. The EPR spectrum of $15 \mathrm{kGy}$ irradiated SD sample.

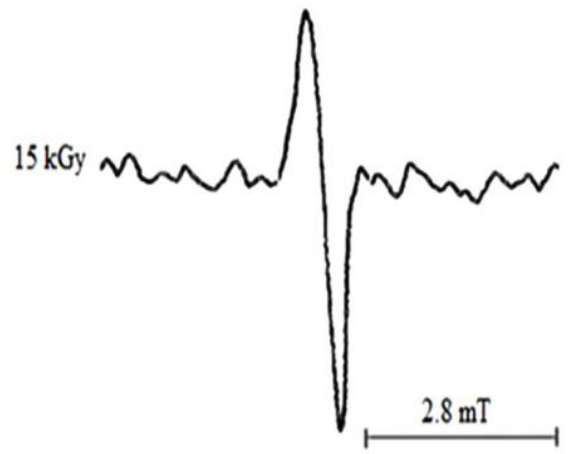

Figure 5. The EPR spectrum of $15 \mathrm{kGy}$ irradiated PA sample.

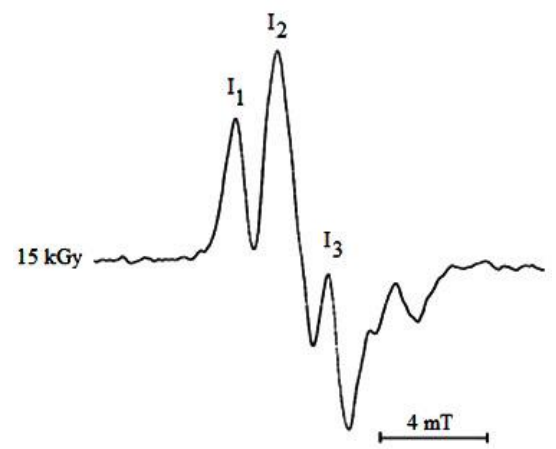

Figure 6. The EPR spectrum of $15 \mathrm{kGy}$ irradiated $\mathrm{CP}$ sample.
EPR signal intensities of SD and PA samples depending on radiation dose applied are given in Figs. 7 and 8, respectively; while the change graph of 3 resonance peaks of $\mathrm{CP}$ sample obtained after irradiation depending on the dose of radiation applied is displayed in Fig. 9.

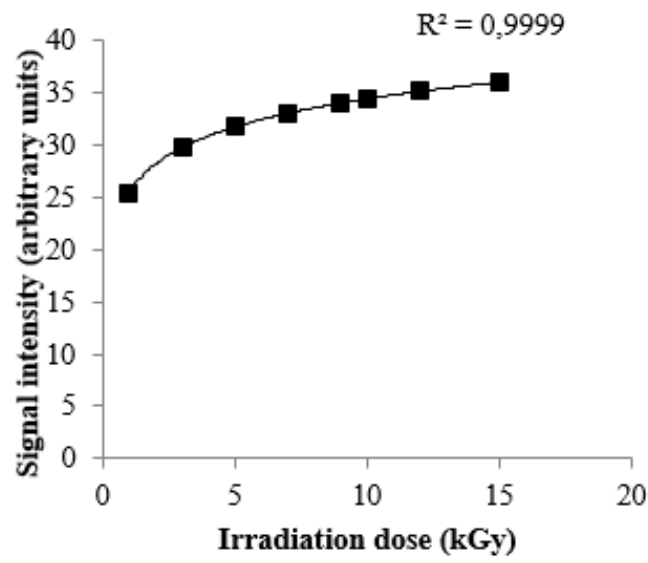

Figure 7. Dose-response curve of SD sample.

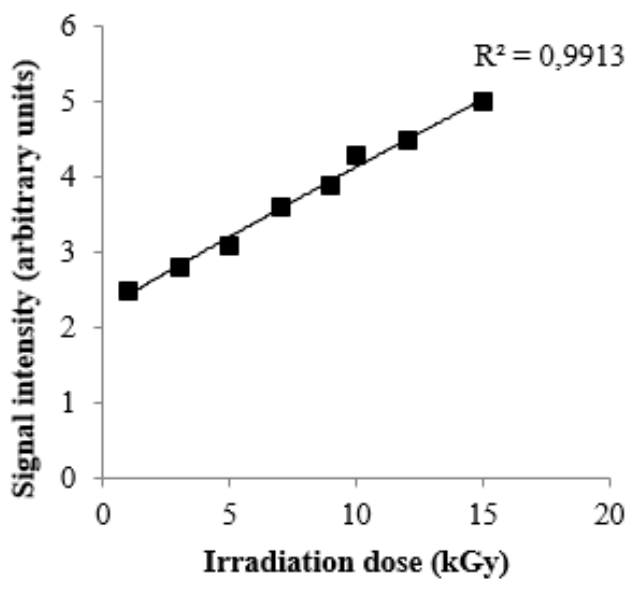

Figure 8. Dose-response curve of PA sample.

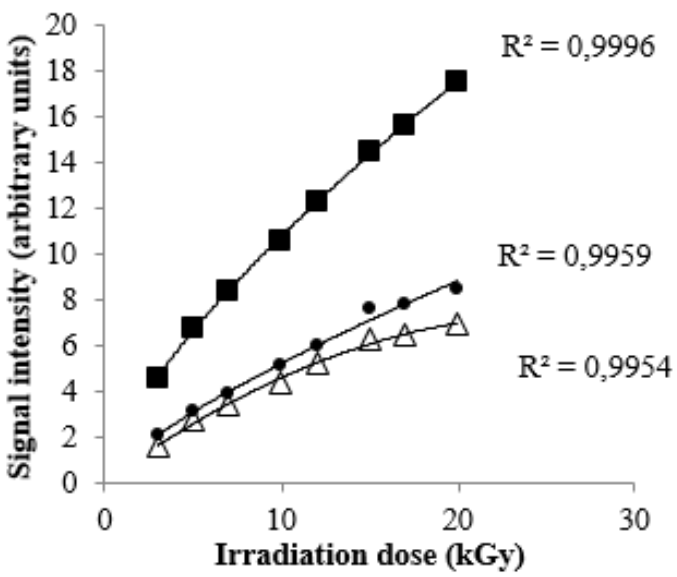

Figure 9. Dose-response curve of CP sample. Signal $\mathrm{I}_{1}(\Delta)$, Signal $\mathrm{I}_{2}(\boldsymbol{\bullet})$,Signal $\mathrm{I}_{3}(\bullet)$. 
In the graphs; $\mathbf{m}, \Delta$ and $\bullet$ signs represent experimental results; while curves connecting them represent the closest mathematical functions to experimental results. The choice of mathematical functions is quite important to determine the amount of absorbed radiation dose by measuring peak to peak signal intensities of the samples. However, there is no single ideal method for this selection. Mathematical equations that show the best fit of the samples and correlation coefficient $\left(\mathrm{R}^{2}\right)$ are given in Table 2. This comment agrees with results obtained for various kind of drugs studied before [26,27]. In these functions, I and $\mathrm{D}$ are used for EPR signal intensity and treated irradiation dose in kGy, respectively and other parameters are constants to be determined. Considering Table 2; the best fit of SD sample seems to be with logarithmic function and the best fit of PA sample is with linear function, respectively.

Table 2. Mathematical functions calculated for dose-response curve of gamma irradiated SD, PA, and CP samples.

\begin{tabular}{lcccccc}
\hline \multirow{2}{*}{ Functions } & \multirow{2}{*}{ Symbol } & \multirow{2}{*}{ SD sample } & PA sample & \multicolumn{3}{c}{ CP sample } \\
\cline { 5 - 6 } & & & & $\mathbf{I}_{\mathbf{1}}$ & $\mathbf{I}_{\mathbf{2}}$ & $\mathbf{I}_{\mathbf{3}}$ \\
\hline $\mathrm{I}=\mathrm{aD}+\mathrm{b}$ & $\mathrm{a}$ & 0.6834 & 0.1858 & 0.3796 & 0.8125 & 0.4707 \\
& $\mathrm{~b}$ & 27.204 & 2.2723 & 0.6434 & 2.475 & 0.7204 \\
$\mathrm{I}=-\mathrm{aD}{ }^{2}+\mathrm{bD}+\mathrm{c}$ & $\mathrm{R}^{2}$ & 0.8612 & 0.9910 & 0.9951 & 0.9968 & 0.9970 \\
& $\mathrm{a}$ & 0.0583 & 0.0007 & 0.0041 & 0.0106 & 0.0061 \\
& $\mathrm{~b}$ & 1.6001 & 0.1966 & 0.4536 & 1.0028 & 0.5800 \\
& $\mathrm{c}$ & 24.718 & 2.2432 & 0.3823 & 1.8037 & 0.3349 \\
$\mathrm{I}=\mathrm{aln}(\mathrm{D})+\mathrm{b}$ & $\mathrm{R}^{2}$ & 0.9757 & 0.9913 & 0.9966 & 0.9989 & 0.9991 \\
& $\mathrm{a}$ & 3.8926 & 0.9104 & 2.8148 & 6.0249 & 3.4864 \\
$\mathrm{I}=\mathrm{aD}$ & $\mathrm{b}$ & 25.519 & 2.0798 & -1.766 & -2.683 & -2.259 \\
& $\mathrm{R}^{2}$ & 0.9999 & 0.8512 & 0.9678 & 0.9694 & 0.9673 \\
$\mathrm{I}=\mathrm{ae}$ & $\mathrm{a}$ & 25.717 & 2.2668 & 0.6713 & 2.1268 & 0.8052 \\
& $\mathrm{~b}$ & 0.1275 & 0.2610 & 0.8271 & 0.7056 & 0.8346 \\
& $\mathrm{R}^{2}$ & 0.9968 & 0.9039 & 0.9950 & 0.9994 & 0.9995 \\
& $\mathrm{a}$ & 27.268 & 2.4297 & 1.4249 & 4.014 & 1.7132 \\
& $\mathrm{~b}$ & 0.0220 & 0.0514 & 0.1064 & 0.0916 & 0.1079 \\
\hline
\end{tabular}

Considering changes in the signals labelled with $\mathrm{I}_{1}, \mathrm{I}_{2}$ and $\mathrm{I}_{3}$ of $\mathrm{CP}$ sample depending on increased radiation dose; similar to microwave changes, $I_{1}$ signal is determined to behave differently from $I_{2}$ and $I_{3}$ signals. It has been determined that the best fit of $\mathrm{I}_{1}$ signal is the function of $\mathrm{I}=a D^{2}+b D+c\left(R^{2}=\right.$ 0.9966), whereas the best fit for $I_{2}$ and $I_{3}$ signals is the function of $\mathrm{I}=\mathrm{aD}^{\mathrm{b}}\left(\mathrm{R}^{2}=0.9994\right.$, $\mathrm{R}^{2}=0.9995$ ). According to this result, in parallel with microwave change, it can be stated that at least two types of free radical are formed in the sample of $\mathrm{CP}$ after irradiation. In addition, SEM images of the samples are obtained in order to see whether gamma radiation has any effect on the surfaces of the samples either non-irradiated or irradiated by gamma rays in $15 \mathrm{kGy}$. In Figs. 10a-10f SEM images of the irradiated and non-irradiated $\mathrm{SD}, \mathrm{PA}$ and $\mathrm{CP}$ samples are presented, respectively. Considering SEM images of the samples, irradiation didn't cause any changes on the surfaces of the samples. 


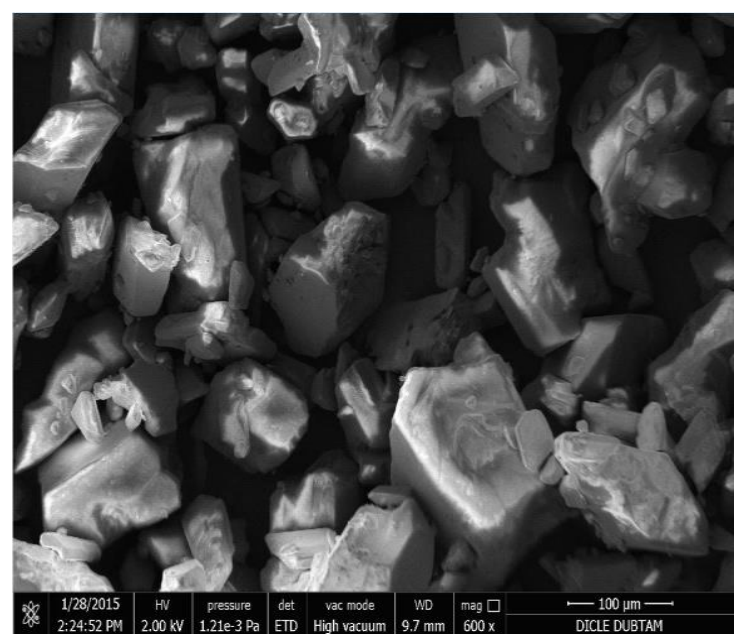

Figure 10a. SEM image of unirradiated SD sample.

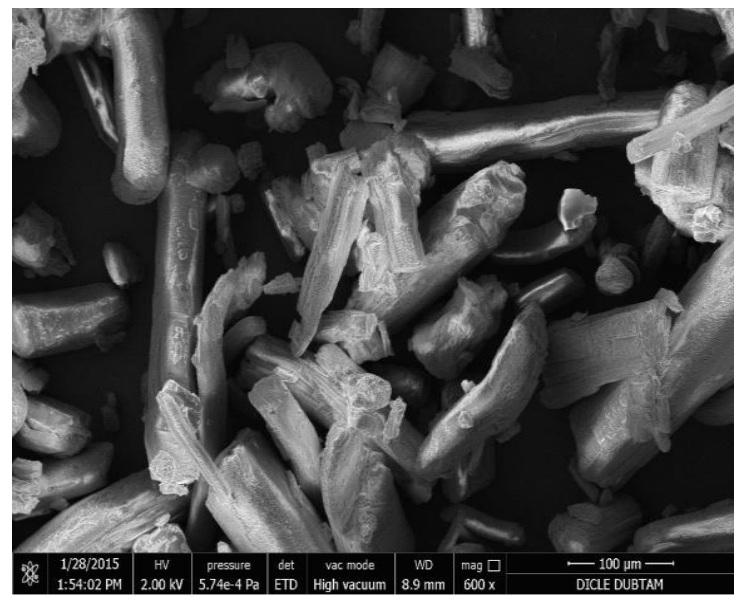

Figure 10c. SEM image of unirradiated PA.

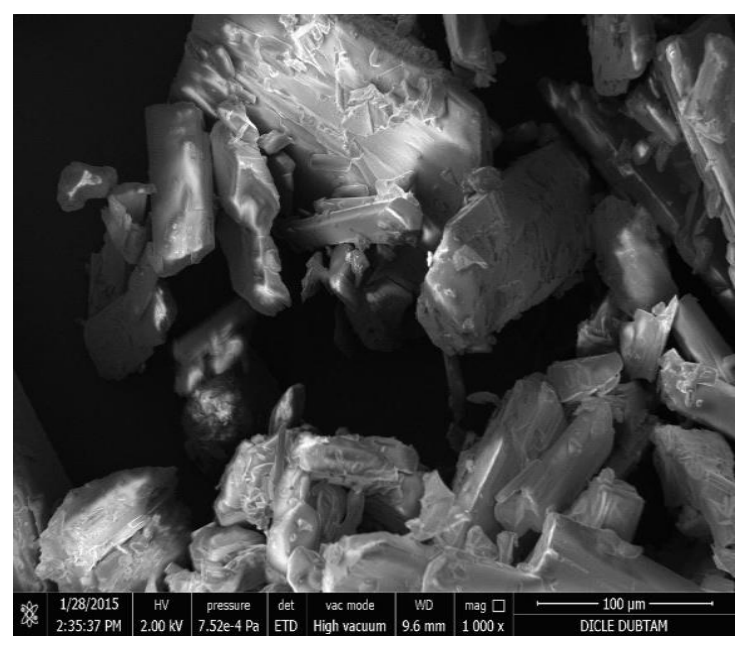

Figure 10e. SEM image of unirradiated CP sample.

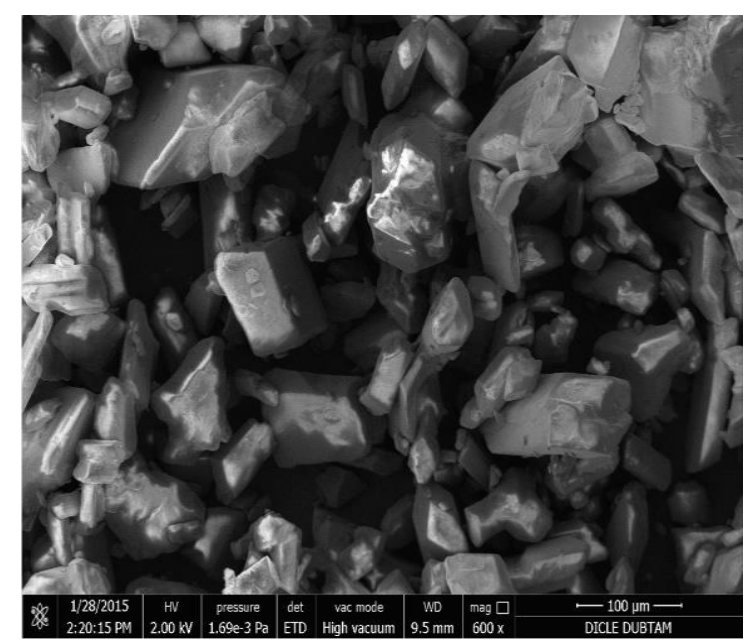

Figure 10b. SEM image of irradiated SD sample.

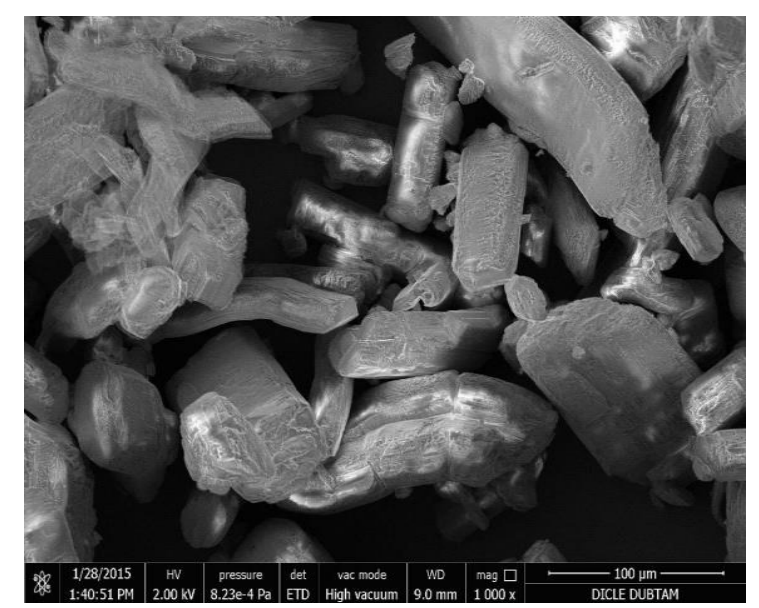

Figure 10d. SEM image of irradiated PA sample.

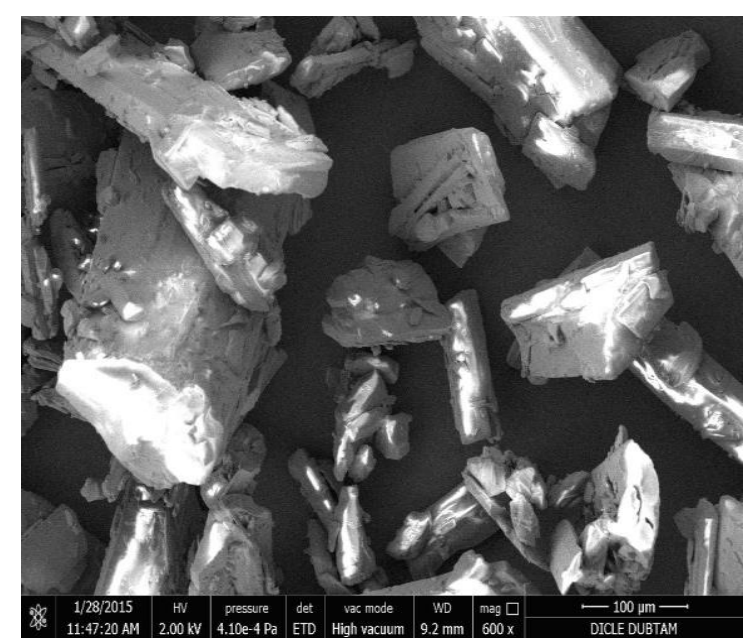

Figure 10f. SEM image of irradiated CP sample.

\subsection{Radical Decays at Room Temperature}

The signals created depending on irradiation of drugs should be capable of being tested during their shelf lives [28]. EPR spectrums of all three samples were recorded at room temperature 
within regular intervals in the daily process of 260 days. In the spectra obtained, no significant changes in the shape of EPR signals and $g$ values were observed, while significant decrease was identified in the signal intensities. Decreased signal intensities indicate that the number of free radicals formed after irradiation also reduced. Throughout the process, samples were stored in an airtight and dark environment at room temperature. Decay curves of SD and PA samples irradiated by $15 \mathrm{kGy}$ are given in Figs. 11 and 12, respectively.

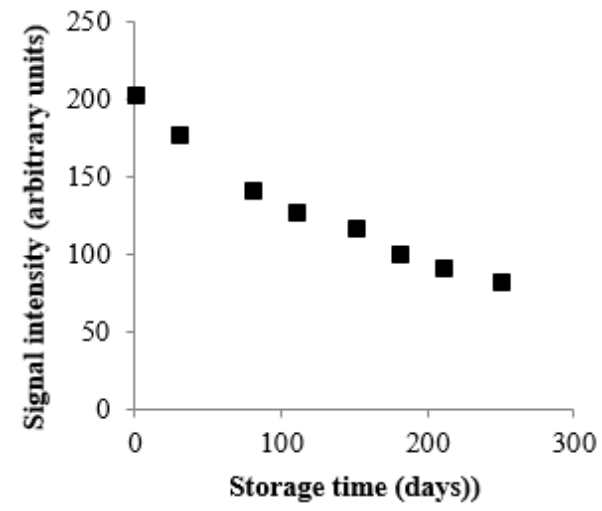

Figure 11. EPR signal intensity of SD sample irradiated at a dose of $15 \mathrm{kGy}$ as a function of time.

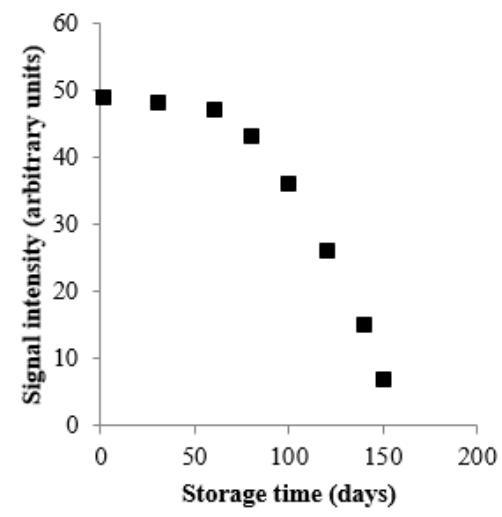

Figure 12. EPR signal intensity of PA sample irradiated at a dose of $15 \mathrm{kGy}$ as a function of time.

Considering Fig. 11, according to spectra of SD sample recorded at the end of $160^{\text {th }}$ day after irradiation, peak to peak signal intensity was reduced by $57 \%$, whereas it was reduced by $60 \%$ at the end of the $250^{\text {th }}$ day, respectively. These data show that even at the end of the $250^{\text {th }}$ day, SD sample can be easily distinguished from non-irradiated sample by EPR technique.
On the other hand, the decay rate of signal intensity of PA sample seems rather slower in the first three months after irradiation; however, the decrease in the signal intensity of PA sample seems faster after three months (Fig. 12). In the EPR spectra recorded at the end of the $80^{\text {th }}$ day, the central signal intensity was reduced by $12 \%$ compared to the signal intensity recorded right after irradiation. Furthermore, at the end of the $150^{\text {th }}$ day, only $14 \%$ of the signal intensity is observed. At the end of the $250^{\text {th }}$ day, no signal intensity was observed in the EPR spectrum of PA sample.

In Fig. 13, decay rates of signals labelled with $I_{1}, I_{2}$ and $I_{3}$ of $C P$ sample are presented. In the first 80 days, the reduction in the $\mathrm{I}_{2}$ signal was calculated as $3 \%$, whereas it was $23 \%$ and $15 \%$ for $I_{1}$ and $I_{3}$ signals, respectively. According to calculations based on spectra taken at the end of the $150^{\text {th }}$ day, $\mathrm{I}_{1}, \mathrm{I}_{2}$, and $\mathrm{I}_{3}$ signals have preserved $56 \%, 68 \%$ and $51 \%$ of their signal intensities, respectively. Since all three signals are visible despite weakly in the spectrum of irradiated $\mathrm{CP}$ sample recorded at the end of the $250^{\text {th }}$ day, it has been shown that irradiated CP sample can be easily distinguished from non-irradiated sample by using EPR spectrometry method even at the end of the $250^{\text {th }}$ day.

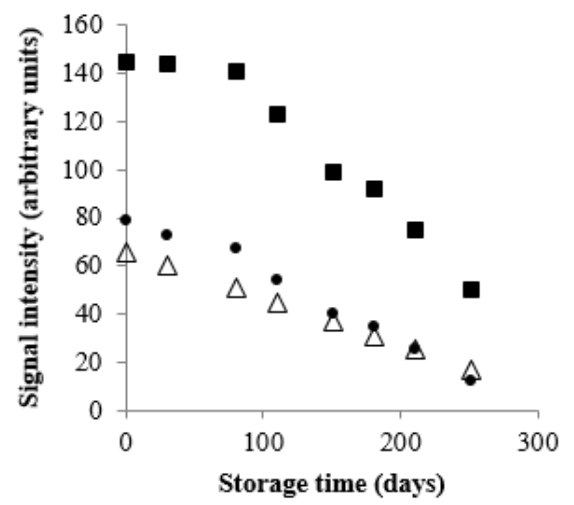

Figure 13. EPR signal intensity of $\mathrm{CP}$ sample irradiated at a dose of $15 \mathrm{kGy}$ as a function of time. Signal $\mathrm{I}_{1}(\Delta)$,Signal $\mathrm{I}_{2}(\mathbf{\bullet})$, Signal $\mathrm{I}_{3}(\bullet)$.

\section{CONCLUSION}

Since no EPR signal is observed in the nonirradiated samples and signals are clearly seen 
in all samples after irradiation, it is very obvious that free radicals are created in all the samples after irradiation. It has been concluded that at least two types of free radicals are formed in CP samples since peak to peak signal intensity of $\mathrm{I}_{1}$ showed different development compared to $\mathrm{I}_{2}$ and $\mathrm{I}_{3}$ signals as microwave power and radiation dose were increased. Increasing irradiation dose up to $15 \mathrm{kGy}$ has increased the signal intensities of the samples; however, no significant change was observed in their $\mathrm{g}$ spectroscopic splitting factors. Obtaining visible signals in the spectrums of samples, which were stored at room temperature, even after 200 days of gamma irradiation shows that stable radicals are formed in these samples after irradiation process. This result shows that samples are not suitable for sterilization by radiation. Considering SEM images of all samples either non-irradiated or irradiated by 15 $\mathrm{kGy}$; since irradiation process didn't create any significant difference on the surfaces of samples, it has been determined that SEM screening method cannot be used to distinguish irradiated and non-irradiated samples from each other.

According to the analyses conducted, EPR spectroscopy can be used to distinguish irradiated and non-irradiated drug samples. The high correlation between experimental results of the samples on the dose-response curves and mathematical equations allows us to calculate the signal intensity of a sample obtained in any dose value.

In this dosimetric study conducted with EPR spectroscopy, radiation sensitivities of all three drugs were determined in addition to EPR parameters of the radicals formed in the samples after irradiation.

\section{ACKNOWLEDGMENT}

This study was funded by Grant No.12-FF-09 of Research Fund of Dicle University (DUBAP).

\section{REFERENCES}

[1]. Gopal N.G.S., Radiation Sterilization of Pharmaceuticals and Polymers, Radiat. Phys. Chem., 12 (1978) 35-50.

[2]. Diehl J.F., Food Irradiation-Past, Present and Future, Radiat. Phys. Chem., 63 (2002) 211-215.

[3]. Bhat R. and Sridhar K.R., Influence of Ionizing Radiation and Conventional Food Processing Treatments on the Status of Free Radicals in Lotus Seeds: An ESR Study, J. Food Comp. Anal., 24 (2011) 563-567.

[4]. Aleksieva K., Lagunov O., Dimov K. and Yordanov N.D., EPR Study on Non-and Gamma-Irradiated Herbal Pills, Radiat. Phys. Chem., 80 (2011) 767-770.

[5]. Ambroż H.B., Kornacka E.M., Marciniec B. and Przybytniak G., Radical Decay in Irradiated Drugs: Flutamide, Ifosfamide, J. Radioanalyt. Nucl. Chem., 254 (2002) 293-298.

[6]. Basly J.P., Bernard M. and Basly I., Electron Spin Resonance Detection of Radiosterilization of Pharmaceuticals: Application to four nitrofurans, Analyst, 123 (1998) 1753-1756.

[7]. Basly J.P. and Bernard M., Radio Sterilization Dosimetry by ESR Spectroscopy: Ritodrine Hydrochloride and Comparison with other Sympathomimetics, Int. J. Pharmaceut., 149 (1997) 85-91.

[8]. Delincée H., Analytical Methods to Identify Irradiated Food-a Review, Radiat. Phys. Chem., 63 (2002) 455-458.

[9]. Karakirova Y. and Yordanov N., Mannitol as a Radiation Sensitive Material for Electron Paramagnetic Resonance Dosimetry, Bulgarian Chem. Commun., 47 (2015) 144-148.

[10].Ambroż H.B., Kornacka E.M., Marciniec B., Ogrodowczyk M. and Przybytniak, G.K., EPR Study of Free Radicals in Some Drugs $\gamma$-Irradiated in the Solid State, Radiat. Phys. Chem., 58 (2000) 357366. 
[11].Basly J.P., Duroux J.L. and Bernard M., Gamma Radiation Induced Effects on Metronidazole, Int. J. Pharmaceut., 139 (1996) 219-221.

[12].Çolak Ş. and Korkmaz M., Spectroscopic Features of Radiolytic Intermediates Induced in Gamma Irradiated Sulfatiazole: an ESR Study, Int. J. Pharmaceut., 285 (2004) 1-11.

[13].Miyazaki T., Arai J., Kaneko T., Yamamoto K., Gibella M. and Tilquin, B., Estimation of Irradiation Dose of Radiosterilized Antibiotics by Electron Spin Resonance: Ampicillin, J. Pharmaceut. Sci., 83 (1994) 1643-1644.

[14].Song K.M., Jeong E., Jeon W., Jo H. and Ban C., A Coordination Polymer Nanobelt (CPNB)-Based Aptasensor for Sulfadimethoxine, Biosen. Bioelectron. 33 (2012) 113-119.

[15].Zhang Y. and Mitchison D., The Curious Characteristics of Pyrazinamide: a Review, Int. J. Tuberc. Lung Dis., 7 (2003) 6-21.

[16].Bhaskar G., Kumar V.S. and Rao B.V., A Short Stereoselective Synthesis of (-)Chloramphenicol and (+)Thiamphenicol. Tetrahedron, Asymmetry, 15 (2004) 1279-1283.

[17].Johansson D., Jessen C.H., Pøhlsgaard J., Jensen K.B., Vester B., Pedersen E.B. and Nielsen P., Design, Synthesis and Ribosome Binding of Chloramphenicol Nucleotide and Intercalator Conjugates, Bioorg. Med. Chem. Lett., 15 (2005) 20792083.

[18].Basly J.P., Basly I. and Bernard M., Electron Spin Resonance İdentification of Irradiated Ascorbic Acid: Dosimetry And Influence of Powder Fineness, Anal. Chim. Acta, 372 (1998) 373-378.

[19].Çolak Ş. and Korkmaz M., Investigation of Structural and Dynamic Features of the Radicals Produced in Gamma Irradiated Sulfanilamide: an ESR Study, Int. J. Pharmaceut., 267 (2003) 49-58.

[20].Marrale M., Longo A., Panzeca S., Gallo S., Principato F., Tomarchio E. and Zeffiro
A., ESR Response of Phenol Compounds for Dosimetry of Gamma Photon Beams, Nucl. Instrum. Meth. Phys. Res. Sect. B: Beam Interact. Mater. Atoms, 339 (2014) 15-19.

[21].Damian G., EPR Investigation of $\gamma$ Irradiated Anti-Emetic Drugs, Talanta, 60 (2003) 923-927.

[22].Polat M. and Korkmaz M., Effect of Gamma Radiation on Amlodis and Its Potential for Radiosterilization, J. Pharmaceut. Biomed. Anal., 40, (2006) 882-888.

[23].Mercanoğlu G.O., Özer A.Y., Çolak Ş., Korkmaz M., Özalp M., Ekizoğlu M. and Tilquin B., Radiosterilization of Sulfonamides: I: Determination of the Effects of Gamma Irradiation on Solid Sulphonamides, Radiat. Phys. Chem., 69 (2004) 511-520.

[24].Basly J.P., Radiation Induced Effects on Cephalosporins: an ESR Study, Int. J. Radiat. Biol., 75 (1999) 259-263.

[25].Gibella M., Crucq A.S., Tilquin B., Stocker P., Lesgards G. and Raffi J., Electron Spin Resonance Studies of Some Irradiated Pharmaceuticals, Radiat. Phys. Chem., 58 (2000) 69-76.

[26].Yurus S., Ozbey T. and Korkmaz, M., ESR Investigation of Gamma Irradiated Sulbactam Sodium, J. Pharmaceut. Biomed. Anal., 35 (2004) 971-978.

[27].Tuner H. and Korkmaz M., Radiostability of Butylated Hydroxytoluene (BHT): An ESR Study, Nucl. Instrum. Meth. Phys. Res. Sect. B: Beam Interact. Mater. Atoms, 258, (2007) 388-394.

[28].Basly J.P., Longy I. and Bernard M., Radiosterilization Dosimetry by ElectronSpin Resonance Spectroscopy: Cefotetan, Anal. Chim. Acta, 359 (1998) 107-113. 